\title{
Does Gender and Race Have an Impact on Earnings in the Library and Information Science Labor Market in the United States of America?
}

\author{
Darren Sweeper \\ Social Sciences Librarian/Assistant Professor \\ Seton Hall University Libraries \\ South Orange, NJ 07079 USA \\ sweepeda@shu.edu
}

Steven A. Smith, Ph.D.

Associate Professor

Department of Management

University of New Orleans

New Orleans, LA 70148 USA

steven.smith@uno.edu

\begin{abstract}
Using data from the 2003 US National Survey of College Graduates, a longitudinal survey administered by the US Bureau of Census for the National Science Foundation, this study examines earnings in the library and information science labor market and assesses the impact of gender and race on the earnings attainment process. This cross-sectional dataset is used to determine if there are significant differences in income among library and information science professionals with respect to gender and race. The approach taken in this study is to build a theoretical model of earnings attainment for librarians and information scientists. This is followed by a discussion of the methodology used to analyze the data and test the model, and the results, discussion including recommendations for further research, and conclusions.
\end{abstract}

\section{Introduction}

Library and information science (LIS) is a field that is changing rapidly as technological advances increase and the amount of information available continues to proliferate. As the field evolves, opportunity and equity among those employed continues to take on greater importance. Finding, retaining, and promoting skilled professionals to manage and change with the field is a challenge the profession is confronting (Kim, Chiu, Sin \& Robbins, 2007; Seaman, 2005). These developments illustrate the importance of issues such as fairness in career attainment processes, which is why studies of attainment in library and information science are needed. This study will propose and test a model of earnings attainment for the LIS labor market and attempt to explain the factors that have an impact on earnings. It is important to note that this study focuses on people who are employed in library and information science and may or may not be librarians as commonly defined by the profession.

This study is organized as follows. First, a review of the relevant literature is presented. Second, the model of earnings attainment is presented along with the theoretical basis of the model and the variable included. Third, the data and analytical framework used in this study is described in the methodology section. This is followed 
by a discussion the results, conclusions, limitations of the study, and implications for further research.

\section{Problem Statement}

The present study examines earnings in the library and information science labor market in the USA in relation to individual, job and labor market variables. Individual variables include demographic, family, and education factors. These are individual variables that have been shown in the research literature to impact earning in various professions and labor markets. Job variables include factors such as whether one is a supervisor or manager, is a member of one or more professional societies, and how active they are in the profession, measured by the number of professional meetings attended within a twelve month period. Labor market variables focus on the sector of employment (public, private, self-employed) and region of the country.

This study contributes to the LIS literature by providing new knowledge and insights concerning the earnings attainment process for professionals employed as librarians and information scientists in the United States. It determines if there are differences in earnings between men and women and white, black, Hispanic, and Asians and whether those differences are statistically significant. This is a new approach for LIS research on salaries, and this knowledge may help researchers, library managers and administrators understand the key factors that influence earnings in the library and information science labor market.

\section{Literature Review}

The literature review that follows explores the field of library and information science, the growth of the labor market and the research on gender and racial differences is reviewed. Then the research on earnings attainment in related labor markets and the factors that influence the process is examined. These areas of research form the basis of this study, the proposed model, and the analysis that follow.

This study views LIS as a single profession and labor market. This is important to mention because there is considerable discussion in the literature on whether or not LIS is truly one cohesive or two distinct fields (Aharony, 2006; Burke, 2007; Hjorland. 2000). This must to be acknowledged in any empirical analysis of LIS because the way the field is defined will determine the outcome of the results. This debate has been ongoing for some time, and strong arguments have been presented on all sides (Borko, 1968; Burke, 2007; Crosby, 2000; Fleck \& Bowden, 1995; Hayes, 1969; Marco, 1996; Prins \& De Gier, 1992; Stieg, 1992; Taylor, 1966). From the emergence of librarianship and information science as disciplines with distinct histories, to the transition to library science and now library and information science, the field has been in a constant mode of change and development. Since the 1990s, information technology has been a major driver of change in librarianship. The impact can be seen throughout the field from the structure and responsibilities of library jobs to changes in curricula and even the names of schools of library and information science worldwide (Aharony, 2006). 
From an analytical perspective, LIS is a broad discipline consisting of various fields, technologies, theories, and knowledge-producing domains; nevertheless, the competing views and strains among the fields are acknowledged in the study (Hjorland, 2000, Marco, 1996; Olsson, 1995). Olsen (1995) provides a comprehensive framework for understanding and analyzing LIS as a cohesive field. She presents her framework as a two-by-two matrix based on the following dimensions: 1) specialist vs. generalist, and; 2) form vs. content. The first dimension differentiates technical form on one end of the continuum from content, meaning content of knowledge, information or subject matter, on the other end. The second dimension differentiates the generalist from the specialist. This matrix provides an excellent framework to analyze LIS as a profession and labor market. It captures the interdisciplinary nature of the field and also acknowledges the key differences between the sub-areas. Hjorland (2000, p. 503) provides the following examples of the types of jobs in each quadrant of Olsson's framework:

Table 1 - Model for professional groups within LIS

\begin{tabular}{|l|l|}
\hline \multicolumn{1}{|c|}{ Quadrant } & \multicolumn{1}{c|}{ Job } \\
\hline 1. Specialist-Technical Form & Producers of data-files (e.g. cataloguers) \\
\hline 2. Specialist-Content & Subject specialists \\
\hline 3. Generalist-Technical Form & System designers \\
\hline 4. Generalist-Content & Information managers \\
\hline
\end{tabular}

Having adopted the view of LIS as an organized, interconnected discipline with many fields, the foundation is set for the discussion that follows. The advancement of LIS as a unified discipline is one of the outcomes of the transition to the information age and the impressive rate of technological developments such as computing, automation and the growth of the Internet. This has led to a growth of specialty jobs such as systems librarians, electronic resources librarians, and subject specialists (Bergman, 2005; Churched, 2003; Lundy, 2003; Scarth, 2002). Many argue that the profession is moving away from the traditional service role to more of a consulting role, assisting and advising library users to become more self-sufficient and focusing more on digital and e-resources (Bergman, 2005; Fidishun, 2001). Grimes and Grimes (2008) argue that the structural changes taking place is resulting in a "shift of skills" required for librarians.

LIS is still perceived as a female-dominated profession. According to Maatta (2007), women comprise about 80 percent of the entire library and information science workforce and 74 percent of jobs in academic libraries. As with other female-dominated professions, this has led to some negative perceptions of the field (Smith, Hartman \& Crow, 2005). Some argue that librarians are perceived as less professional than other professions because of their focus on service (Bergman, 2005). Others argue that it is the result of its composition of women and its image as a feminized profession (Piper \& Collamer, 2001). As it relates to salary and earnings attainment, what is happening in the field is consistent with similar developments in other professions. For example, studies have shown that the higher the composition of women in a profession, the lower the prestige and salaries compared to similar fields dominated by men (Graham \& Smith, 2005). 
There have been a number of studies over the past twenty years investigating gender differences in LIS. These studies cover a range of topics, from exploring the role of men in a field that is predominantly female (Carmichael, 1992; Passet, 1993; Piper \& Collamer, 2001), to the composition of men and women in various jobs and roles within the field (Charters \& Grimes, 1997; Hildenbrand, 1999). A large portion of this research examines issues of gender equity and parity in career development and attainment (Harris \& Tague, 1989), salary and economic differences among librarians (Ashcroft, 2003; Carson, 1996; Maatta, 2007; Zemon \& Bahr, 2005), and opportunities for promotion into leadership positions (Deyrup, 2004; Turock, 2003). Most of the recent literature on gender differences finds that the opportunity gap between men and women has narrowed significantly since the 1970s and 1980s. Deyrup (2004) argues that women have made substantial gains since 1972 when they held only a small portion of leadership positions in academic libraries. Women are now the majority of top administrators of Association Research Libraries (ARL) institutions, the ARL board of directors, and occupy most of the American Library Association's (ALA) executive board and officer positions. The differences in salary have also decreased substantially, as women have almost achieved parity with their male colleagues (Deyrup, 2004). Other studies have come to similar conclusions, some even finding that female compensation exceeds that of males in many library positions (Zemon \& Bahr, 2005). Overall, there is agreement in the literature that gender differentials in salary and career success has decreased and continues to move in positive directions.

Few studies have examined salary differences among racial groups in LIS. The ALA only began to systematically collect demographic information, including race and ethnicity, from their membership in 2003-2004 (Lynch, 2003). There is increasing interest to study issues of diversity in the field, including the impact of race on earnings; however, a small number of studies have examine racial differences as compared to gender differences. Lynch (2003) has pointed out the need for more understanding of demographic factors among the ALA membership and its importance in enabling the association to know and be able to describe itself to others.

A review of the library and information science literature reveals that most of the studies that have analyzed income differences have only compared mean salaries of various demographic groups. In this study, a model of earnings attainment is developed and tested utilizing regression analysis. This method allows us to identify salary differences, if they exist, and whether or not those differences are statistically significant. The next section presents the theoretical basis for the model, followed by the presentation of the model and the results of the analysis in the subsequent two sections.

\section{A Theory of Earnings Attainment}

There are various theoretical perspectives concerning the operation of the labor market that are important to explain, especially in regards to earnings attainment. These theories derive from economic and sociological research on wage differentials and can be roughly categorized into three schools of thought: (1) the status attainment/human capital perspective; (2) the occupationalist perspective; and (3) the structuralist perspective (Auster, 1989; Smith, 1997). The status attainment and human capital perspective 
focuses on individual characteristics and views the labor market as an efficient allocator of wages and career outcomes. According to this point of view, if wage differentials persist after controlling for human capital factors, they are the result of market imperfections (Auster, 1989; Becker, 1964). Human capital theory derives from neoclassical economics and status attainment theory from sociology (Auster, 1989; Hauser, 1980). Both assume work structures are constant and not necessary to explain labor market processes. According to Becker (1964), activities that influence future monetary and psychic income by increasing resources in people are called investments in human capital. These resources include factors such as education, training, work experience, and other factors that would make an individual more attractive and employable to prospective employers. As with neoclassical economic theory, these models assume perfect mobility, which implies the absence of non-economic barriers such as discrimination (Beggs, 1995). This approach to labor market analysis usually requires the development of earnings attainment models that include quantifiable human capital variables hypothesized to influence the determination of wages.

The occupationalist perspective contends that significant earnings differentials are due to segregation of jobs based on irrelevant characteristics such as gender and race (Baron, 1991; Bielby, 1991). Occupationalist focus on both individual and occupational factors to explain differences in wages. They argue that certain occupations, especially low-paying ones with dead end career paths and limited opportunities, are disproportionately staffed by women and minorities. An example of this view is dual labor market theory which maintains that jobs in the labor market can be roughly divided into two categories: primary and secondary jobs (Averitt, 1968; Bluestone, Murphy \& Stevenson, 1973; Doeringer \& Piore, 1971). Primary jobs are those in the upper or elite stratum of the labor market, and are described as having high wages, good working conditions, and opportunities for advancement. Secondary jobs are considered to be lowpaying with poor working conditions and little or no opportunities for advancement.

There are various perspectives within the structuralist school of thought. The common theme is the emphasis on the demand side of the labor market and the role that organizations, industries, and labor markets play in the allocation of jobs and wages. Structuralists argue that emphasis only on supply side characteristics such as human capital factors fail to recognize the influence of demand side factors such as organizational structures, industry dynamics, labor market, and institutional variables. Therefore, they focus on firm, industry, environmental, and individual characteristics in research on earnings attainment in an attempt to develop multivariate models of work and labor market processes (Baron \& Bielby, 1980; Granovetter, 1981; Kalleberg, Wallace \& Althauser, 1981).

All three perspectives focus on the individual as the unit of analysis. The key difference between occupationalist and structuralist theories, and human capital and status attainment theory, is the emphasis on social constraints in individual mobility in the labor market (Granovetter, 1992). Occupational and structural theories stress the concept of embeddedness if labor market behavior in social networks and demographic constraints (Granovetter, 1985; Portes \& Sensenbrenner, 1993), whereas human capital and status attainment theories emphasize the role of the individual, whose behavior is 
viewed as being independent of current and historically exogenous influences Becker, 1964). The extensive research in this area has confirmed that the inclusion of multi-level, multi-factor variables explains more variance in wage determination models than models based only on individual-level factors (Smith, 1997). In this study, a multivariate structural model of earnings attainment is developed and tested for those employed in the library science labor market in the United States. The objective is to determine their attainment profiles and whether or not the process is influenced by demographic factors such as gender, race and ethnicity.

\section{The Model of Earnings Attainment in Library and Information Science}

Most of the current research on earnings across professions and labor markets are based on multivariate models built to consider the influence of multiple categories of variables. Building on the theories presented in the previous section, the three categories of variables included in this study are as follows: 1) individual factors; 2) job/occupational factors; and 3) labor market factors. Each category is believed to contribute to the earnings process in library science. Grimes and Grimes (2008) used similar categories in their recent study of the role of education in the labor market for academic librarians. This multivariate perspective takes into account the complex nature of labor markets and the fact that many factors, economic and non-economic, contribute to economic outcomes (Baron \& Bielby, 1980). Therefore, it is assumed that the natural log of earnings can be described as follows:

where the dependent variable is earning and I, J, and L represent individual, job, and labor market characteristics, respectively. Equation [2] presents a form of the model that includes the coefficients for each category of variables:

$$
\begin{aligned}
& \text { EARNINGS }=\sum \mathrm{B} i * \text { INDIVIDUAL FACTORS }+\sum \mathrm{B} j * \text { JOB FACTORS }+ \\
& \sum \mathrm{B} k * \text { LABOR MARKET FACTORS }
\end{aligned}
$$

The model of earnings attainment maintains that earnings is a function of three groups of variables, and $\mathrm{B} i \mathrm{~B} j$, and $\mathrm{B} k$, represent the coefficients for each category. Lee (2005) proposed a similar model in her study of academic libraries. She divided the variables into three categories, library/organizational, institutional, and regional variables. Individual variables were not included in Lee's study because they were not available in the data. This study is unique in LIS because of the availability of individual variables, including background and education variables, in addition to organizational and labor market factors.

In much of the research on earnings, individual characteristics such as gender, race, ethnicity, citizenship, age, marital status, and number of children have been shown to impact earnings and are consistently included in the models of attainment (Graham \& Smith, 2005; Grimes \& Grimes, 2008; Pfeffer \& Davis-Blake, 1990, Ransom, 1993, 
Webster, 1995). Since the objective of this study is to assess the impact of gender and race on earnings, it is critical to include all of these factors in the model. In addition to background and demographic variables, the impact of human capital variables on earnings has been illustrated in the research literature (Barbezet, 2003; Becker, 1964; Granovetter, 1981). Educational level is consistently proven to be the human capital variable with the most important impact on income and career attainment, especially in professional segments of the U.S. labor market (Eliason, 1995). Education is measured by the highest degree attained.

The next category of variables included in the model is job factors. The variables included are 1) whether one is a supervisor or manager; 2) if they are a member of a professional organization or society; 3) if they have attended professional meetings, and 4) whether the respondent is a librarian. The "librarian" variable is included based on the differences discussed previously between librarians and information scientists. Traditional librarians tend to earn less than information scientists, and this is controled in the model. Overall, the job-related variables included are not exhaustive, but they do provide insight into job responsibilities and internal library policies, such as support for specialized training and participation in professional activities (Allard, 1984; Grimes \& Grimes, 2008). Labor market factors included in the model are sector of employment (educational, government, self-employment, and non-profit sector compared to the forprofit sector), and geographic region (Graham \& Smith, 2005). The next section presents the data and methodology used to test the model.

\section{Methodology}

The source of data for this study is the 2003 US National Survey of College Graduates (NSCG). It is a longitudinal survey administered by the Bureau of the Census for the National Science Foundation. It is a rich data set with demographic and employment information for over 100,000 college graduates with a baccalaureate degree or higher in 2003. The NSCG provides important information about the education and career paths of the country's college graduates. It also provides valuable data on the characteristics of people in the workforce such as salaries, whether the college-educated population was working in their field of study, specific occupations, sector of employment, employment status, professional training, and a gender and racial breakdown of those employed in the workforce with a college education. The 2003 NSCG provides a wealth of information covering several different topics related to career attainment and labor market dynamics.

The sample for this study consists of 549 college graduates working in library and information science in the United States in 2003. The categories of "librarians" and "information scientists" recorded in the NSCG are combined to form the sample population. These are college graduates of all demographic groups and regions of the United States that chose "librarians" and "information scientists" as the job category that best describes the work they were doing on their principle job in October 2003. No distinction was made between employment in academic, public, private and/or special libraries due to the sample size of those working in the field and the number of variables 
in the proposed model; however, distinctions were made between sectors of employment (i.e., government, profit, non-profit, and the self-employment sectors). One of the limitations in using secondary data, such as the NSCG and other government-sponsored surveys, is that researchers have to work with the variables recorded and the data collected by the principle investigators. One of the challenges encountered in this study is that those employed in library and information science may not all be considered librarians as commonly defined by the profession. The sample includes individuals that have identified themselves as librarians or working in the library science field and as information scientists and specialists, although they may not hold a Master of Library Science degree.

Although this is a small sample, the 2003 NSCG provides one of the few sources of detailed information on LIS professionals at all degree levels in the United States. The sample of 549 includes those working in library and information science with positive income during the month of October 2003, with a baccalaureate degree or higher, and living in the United States. The tables that follow provide descriptive statistics of the sample. The variables in the model of earnings attainment are reported in Table 2 along with their specification and overall sample mean. The dependent variable is earnings, a continuous variable, and the independent variables are a combination of dichotomous, categorical, and continuous variables. The mean of earning is $\$ 56,489.40$. The sample mean of each of the dichotomous independent variables is the percentage of the overall sample with that respective characteristic. These are referred to as "dummy variables" and they denote membership or nonmembership in a given group where membership is assigned a value of 1 , while nonmembership is assigned 0 .

Table 2 - Definition and Full-Sample Means for Variables Used in Model of Earnings Attainment

\begin{tabular}{|c|l|c|}
\hline Variable & \multicolumn{1}{|c|}{ Specification } & Mean (standard deviation) \\
\hline Dependent Variable & \multicolumn{1}{|c|}{ Annual Salary in 2003 } & \$56,592.48 (40,898.27) \\
\hline Earnings & & $0.57(0.50)$ \\
\hline Individual Variables & $\begin{array}{l}\text { Female }=1 \\
\text { Otherwise }=0\end{array}$ & $0.81(0.39)$ \\
\hline Female & $\begin{array}{l}\text { White }=1 \\
\text { Otherwise }=0\end{array}$ & $0.07(0.26)$ \\
\hline White & $\begin{array}{l}\text { Black }=1 \\
\text { Otherwise }=0\end{array}$ & $0.05(0.23)$ \\
\hline Black & $\begin{array}{l}\text { Hispanic Heritage }=1 \\
\text { Otherwise }=0\end{array}$ & $0.11(0.32)$ \\
\hline Hispanic & $\begin{array}{l}\text { Asian }=1 \\
\text { Otherwise }=0\end{array}$ & $0.02(0.15)$ \\
\hline Asian & $\begin{array}{l}\text { Native American }=1 \\
\text { Otherwise }=0\end{array}$ & $46.66(10.88)$ \\
\hline Native American & Age as of October 2003 & $0.71(0.45)$ \\
\hline Age & Married \\
\hline Married & \multicolumn{2}{|l}{}
\end{tabular}




\begin{tabular}{|c|c|c|}
\hline & $\begin{array}{l}\text { Yes }=1 \\
\text { Otherwise }=0\end{array}$ & \\
\hline Foreign-Born & $\begin{array}{l}\text { Born outside the U.S. }=1 \\
\text { Otherwise }=0\end{array}$ & $0.22(0.41)$ \\
\hline Bachelors Degree & $\begin{array}{c}\text { Highest Degree Attained } \\
\text { Bachelors }=1 \\
\text { Otherwise }=0\end{array}$ & $0.29(0.45)$ \\
\hline Masters Degree & $\begin{array}{c}\text { Highest Degree Attained } \\
\text { Masters }=1 \\
\text { Otherwise }=0\end{array}$ & $0.55(0.50)$ \\
\hline Prof. Degree* & $\begin{array}{c}\text { Highest Degree Attained } \\
\text { Prof. Degree }=1 \\
\text { Otherwise }=0\end{array}$ & $0.02(0.15)$ \\
\hline Ph.D. Degree & $\begin{array}{l}\text { Highest Degree Attained } \\
\text { Ph.D. }=1 \\
\text { Otherwise }=0\end{array}$ & $0.14(0.34)$ \\
\hline \multicolumn{3}{|l|}{ Job Variables } \\
\hline Supervisor & $\begin{array}{l}\text { Did you supervise the work } \\
\text { of others as part of your } \\
\text { principle job } \\
\text { responsibilities? } \\
\qquad \begin{array}{l}\text { Yes }=1 \\
\text { No }=0\end{array}\end{array}$ & $0.48(0.50)$ \\
\hline Attends Prof. Mtgs & $\begin{array}{l}\text { During the past year, did } \\
\text { you attend any professional } \\
\text { society or association } \\
\text { meetings or conferences? } \\
\text { Yes = } 1 \\
\quad \text { No }=0\end{array}$ & $0.68(0.47)$ \\
\hline \# of Prof. Societies & $\begin{array}{l}\text { Number of Professional } \\
\text { Society Memberships }\end{array}$ & $1.57(1.56)$ \\
\hline Librarian Job & Works as a librarian & $0.65(0.48)$ \\
\hline \multicolumn{3}{|l|}{ Labor Market Variables } \\
\hline Education Sector & $\begin{array}{c}\text { Education Sector } \\
\qquad \begin{array}{c}\text { Yes }=1 \\
\text { No }=0\end{array}\end{array}$ & $0.39(0.49)$ \\
\hline Government Sector & $\begin{array}{c}\text { Government Sector } \\
\text { Yes }=1 \\
\text { No }=0\end{array}$ & $0.26(0.44)$ \\
\hline Profit Sector & $\begin{array}{r}\text { Profit Sector } \\
\qquad \begin{array}{r}\text { Yes }=1 \\
\text { No }=0\end{array}\end{array}$ & $0.27(0.44)$ \\
\hline Non-Profit Sector & Non-Profit Sector & $0.08(0.27)$ \\
\hline
\end{tabular}




\begin{tabular}{|c|c|c|}
\hline & $\begin{array}{l}\text { Yes }=1 \\
\text { No }=0\end{array}$ & \\
\hline Self-Employed & $\begin{array}{r}\text { Self-Employed } \\
\text { Yes }=1 \\
\text { No }=0\end{array}$ & $0.007(0.085)$ \\
\hline North East U.S. & $\begin{array}{c}\text { Employer Region in U.S. } \\
\text { North East }=1 \\
\text { Otherwise }=0\end{array}$ & $0.24(0.43)$ \\
\hline North Central U.S. & $\begin{array}{c}\text { Employer Region in U.S. } \\
\text { North Central }=1 \\
\text { Otherwise }=0\end{array}$ & $0.18(0.39)$ \\
\hline South Central U.S. & $\begin{array}{l}\text { Employer Region in U.S. } \\
\text { South Central }=1 \\
\text { Otherwise }=0\end{array}$ & $0.10(0.31)$ \\
\hline South East U.S. & $\begin{array}{c}\text { Employer Region in U.S. } \\
\text { South East }=1 \\
\text { Otherwise }=0\end{array}$ & $0.23(0.42)$ \\
\hline Mountain Region & $\begin{array}{c}\text { Employer Region in U.S. } \\
\text { Mountain }=1 \\
\text { Otherwise }=0\end{array}$ & $0.09(0.28)$ \\
\hline Pacific Region & $\begin{array}{c}\text { Employer Region in U.S. } \\
\text { Pacific Region }=1 \\
\text { Otherwise }=0\end{array}$ & $0.16(0.37)$ \\
\hline
\end{tabular}

Among the independent variables, the table shows that the sample is representative of the demographic make-up of LIS based on previous surveys and articles (Kim, Chiu, Sin \& Robbins, 2007; Lim, 2008; Lynch, 1998). The sample is 57 percent female, 81 percent white, 7 percent black, 5 percent Hispanic, 11 percent Asian, and 2 percent Native American; additionally, 22 percent of the sample is foreign-born. The average age of the sample is 46.7 years and 71 percent were married. Most (55\%) posses a Master's degree and 48 percent supervised the work of others. A large 68 percent of the sample attended at least one professional meeting within a one-year period and were member of almost 2 professional societies or associations. Among labor market variables, the largest group in the sample was employed in the education sector (39\%) followed by the for-profit (27\%) and government (26\%) sectors. The sample was almost evenly distributed across the United States, with the largest number (24\%) employed in the North East region of the country and the smallest (9\%) in the Mountain states.

To illustrate the difference between those in traditional library jobs from those in information science, the data in Table 3 presents descriptive statistics for both groups of LIS professionals. 
Table 3 - Descriptive Statistics for Librarians \& Information Scientists in the 2003 US National Survey of College Graduates

\begin{tabular}{|c|c|c|}
\hline Variable & $\begin{array}{l}\text { Librarians } \\
\mathrm{N}=358 \text { ( } 65 \% \text { of Sample) } \\
\text { Mean (standard deviation) }\end{array}$ & $\begin{array}{l}\text { Information Scientists } \\
\mathrm{N}=191 \text { (35\% of Sample) } \\
\text { Mean (standard deviation) }\end{array}$ \\
\hline \multicolumn{3}{|l|}{ Dependent Variable } \\
\hline Salary & $\$ 42,067.79(23,457.30)$ & $\$ 83,740.71(51,451.32)$ \\
\hline \multicolumn{3}{|l|}{ Individual Variables } \\
\hline Female & $0.76(0.43)$ & $0.19(0.40)$ \\
\hline White & $0.85(0.35)$ & $0.72(0.45)$ \\
\hline Black & $0.08(0.27)$ & $0.07(0.26)$ \\
\hline Hispanic & $0.05(0.23)$ & $0.06(0.23)$ \\
\hline Asian & $0.06(0.25)$ & $0.21(0.41)$ \\
\hline Native American & $0.02(0.15)$ & $0.03(0.16)$ \\
\hline Age & $49.46(10.38)$ & $41.44(9.84)$ \\
\hline Married & $0.68(0.47)$ & $0.78(0.42)$ \\
\hline Foreign-Born & $0.12(0.33)$ & $0.39(0.49)$ \\
\hline Bachelors Degree & $0.26(0.44)$ & $0.35(0.48)$ \\
\hline Masters Degree & $0.67(0.47)$ & $0.34(0.48)$ \\
\hline Prof. Degree* & $0.03(0.17)$ & $0.01(0.10)$ \\
\hline Ph.D. Degree & $0.04(0.21)$ & $0.30(0.46)$ \\
\hline \multicolumn{3}{|l|}{ Job Variables } \\
\hline Supervisor & $0.52(0.50)$ & $0.42(0.50)$ \\
\hline Attends Prof. Mtgs & $0.71(0.45)$ & $0.62(0.49)$ \\
\hline \# of Prof. Societies & $1.78(1.68)$ & $1.17(1.22)$ \\
\hline \multicolumn{3}{|l|}{ Labor Market Variables } \\
\hline Education Sector & $0.48(0.50)$ & $0.22(0.41)$ \\
\hline Government Sector & $0.32(0.47)$ & $0.14(0.34)$ \\
\hline Profit Sector & $0.09(0.28)$ & $0.61(0.49)$ \\
\hline Non-Profit Sector & $0.10(0.30)$ & $0.03(0.17)$ \\
\hline Self-Employed & $0.01(0.07)$ & $0.01(0.10)$ \\
\hline North East U.S. & $0.22(0.41)$ & $0.28(0.45)$ \\
\hline North Central U.S. & $0.23(0.42)$ & $0.10(0.30)$ \\
\hline South Central U.S. & $0.13(0.34)$ & $0.06(0.23)$ \\
\hline South East U.S. & $0.20(0.40)$ & $0.27(0.45)$ \\
\hline Mountain Region & $0.08(0.27)$ & $0.09(0.29)$ \\
\hline Pacific Region & $0.14(0.35)$ & $0.20(0.40)$ \\
\hline
\end{tabular}

The differences are large but in line with the way both groups are described in the literature and consistent with many of the reports examining the profession. 
The data in Table 4 contains all 549 LIS professionals and presents education level, measured as highest degree attained, by race, ethnicity and gender, and the data in Table 5 present annual mean income by the same factors. Tables 4 and 5 show differences between the groups by degree and mean annual salary. Although the variation in means reported in Table 5 appear large, the differences may not be significant. In other words, they may be the result of chance, and not based on the impact of any specific variable or set of variables. The purpose of the regression analysis that follows is that it tests whether the differences in the mean annual salary of those in our sample are based on the impact of the independent variables on earnings, or the result of chance.

Table 4 - Education Level by Demographic Group in LIS ( $N=549)$

\begin{tabular}{|l|c|c|c|c|c|}
\hline Category & $\begin{array}{l}\text { Bachelor } \\
\text { Degree }\end{array}$ & $\begin{array}{l}\text { Masters } \\
\text { Degree }\end{array}$ & $\begin{array}{l}\text { Prof. } \\
\text { Degree }\end{array}$ & $\begin{array}{l}\text { Ph.D. } \\
\text { Degree }\end{array}$ & Total \\
\hline Female & 93 & 190 & 10 & 17 & 310 \\
\hline Male & 65 & 113 & 3 & 57 & 238 \\
\hline White & 133 & 247 & 12 & 51 & 443 \\
\hline Black & 13 & 24 & 0 & 4 & 41 \\
\hline Hispanic & 13 & 13 & 0 & 4 & 30 \\
\hline Asian & 12 & 30 & 0 & 21 & 63 \\
\hline Native American & 4 & 6 & 2 & 1 & 13 \\
\hline U.S. Born & 13 & 248 & 13 & 31 & 430 \\
\hline Foreign-Born & 20 & 55 & 0 & 43 & 118 \\
\hline
\end{tabular}

Table 5 - Mean Annual Salary by Demographic Group in LIS ( $N=549)$

\begin{tabular}{|l|c|c|}
\hline \multicolumn{1}{|c|}{ Group } & Mean & Std. Deviation \\
\hline Female & $\$ 46,006.05$ & $40,105.80$ \\
\hline Male & $\$ 70,381.53$ & $37,760.93$ \\
\hline White & $\$ 55,362.42$ & $35,206.39$ \\
\hline Black & $\$ 50,065.27$ & $30,323.03$ \\
\hline Hispanic & $\$ 48,522.37$ & $28,819.92$ \\
\hline Asian & $\$ 68,121.73$ & $72,291.50$ \\
\hline Native American & $\$ 57,121.46$ & $33,910.72$ \\
\hline U.S. Born & $\$ 52,045.14$ & $31,251.97$ \\
\hline Foreign-Born & $\$ 73,163.29$ & $62,337.51$ \\
\hline
\end{tabular}

Table 6 presents the results of the multiple regression analysis on the model of earnings attainment to determine if any of the variables in the model are statistically significant. Multiple regression analysis analyzes the relationship between the dependent variable (earnings), and the three categories of independent variables (individual, job, labor market) included in the model. The objective is to determine how and to what extent variability in earnings depend upon variations of the independent variables. The coefficient $(B)$ on each independent variable in the model of earnings attainment indicates the expected change in earnings associated with a unit change in the independent variable under consideration while controlling for, or holding constant, the effects of the other independent variables. Multiple regression is the superior method of analysis when some of the independent variables are continuous, such as age, and some are categorical, as are 
all of the dummy variables in the model (Pedhazur, 1982). The section following Table 6 describes the results of the analysis.

Table 6 - Regression Results

Dependent Variable: Earnings $(\mathrm{N}=549)$

\begin{tabular}{|c|c|c|c|}
\hline \multirow[b]{2}{*}{ Variable } & \multicolumn{2}{|c|}{ Coefficients $(B)$} & \multirow[t]{2}{*}{ Significance } \\
\hline & B & Std. Error & \\
\hline Asian & -7071.41 & 5096.10 & .166 \\
\hline Black & -4866.30 & 5333.83 & .362 \\
\hline Hispanic & -11447.37 & 6076.83 & .060 \\
\hline Female & 2313.18 & 3326.59 & .487 \\
\hline Foreign-Born & 937.85 & 4228.58 & .825 \\
\hline AGE & $361.56^{\star \star}$ & 135.18 & .008 \\
\hline Married & $7794.66^{*}$ & 3301.94 & .019 \\
\hline Children & 1400.03 & 2977.91 & .638 \\
\hline Masters Degree & $7110.78^{*}$ & 3386.27 & .036 \\
\hline Professional Degree & 10535.48 & 9266.55 & .256 \\
\hline PhD Degree & $25073.59^{\star \star \star}$ & 5153.63 & .000 \\
\hline Supervisor & $13225.65^{\star \star \star}$ & 2821.99 & .000 \\
\hline Prof. Meetings Attended & 5210.34 & 3446.79 & .131 \\
\hline $\begin{array}{l}\text { Number of Prof } \\
\text { Societies }\end{array}$ & $2200.54^{*}$ & 1033.21 & .034 \\
\hline Education Sector & $-27114.13^{\star \star \star}$ & 4175.61 & .000 \\
\hline Government Sector & $-19620.72^{\star \star \star}$ & 4363.06 & .000 \\
\hline Non-Profit Sector & $-21206.54^{\star \star *}$ & 6026.35 & .000 \\
\hline Self-Employed Sector & $-37090.35^{\star}$ & 16234.27 & .023 \\
\hline Southeast Region & -6092.33 & 4048.12 & .133 \\
\hline North Central Region & $-15429.38^{* \star *}$ & 4303.06 & .000 \\
\hline South Central Region & $-13849.16^{\star *}$ & 5173.44 & .008 \\
\hline Mountain Region & $-15397.26^{\star *}$ & 5442.41 & .005 \\
\hline Pacific Region & 31.88 & 4457.26 & .994 \\
\hline Librarian Job & $-30155.63^{\star \star *}$ & 4232.91 & .000 \\
\hline (Constant) & 56982.40 & 7489.12 & .000 \\
\hline Adjusted R-Square & 0.415 & & \\
\hline
\end{tabular}

Dependent Variable: SALARY ANNUALIZED

Note: The omitted variables are white, bachelor's degree, profit sector, and Northeast region.

\section{Findings}

Regression estimates of how individual, job and labor market factors impact earnings in LIS presented in table (6) provide interesting insights of the earnings attainment process. The model yields an adjusted r-squared of 0.415 , which means that 41.5 percent of the variance in earnings is explained by the variables in the model. The results also reveal a set of statistically significant variables. The column labeled "Significance" in table (6) provides the probability for each variable that a difference as large as the one observed would occur in the sample if in the sample if in the population there were no difference in the means. If the probability is large (over 0.50), then the 
variable is deemed not significant. Significance in this study is determined by probabilities of 0.50 or less. In table (6), three categories of significance is noted: 1) probability between 0.01 denoted by one asterisk; and $0.50,2$ ) probabilities between 0.01 and 0.001 , denoted by two asterisks; and 3) probabilities of 0.001 or less, denoted by three asterisks. The level of significance is greater the smaller the probability presented in table (6). As the impact of gender, race, and ethnicity on earnings is examined, the major finding of the analysis is that there are no significant differences between men and women, and between the racial and ethnic groups.

The coefficient of age (361.56) is positive and significant $(p<0.01)$, which can be interpreted as a one-year increase in age leads to a \$361.56 increase in salary, after statistical adjustment for the remaining independent variables in the model. Age can also be considered a proxy for years of work experience, which is not in the model, as the two variables are usually highly correlated. One of the family-related variables is also significant. Being married has a positive and significant $(p<0.05)$ impact on earnings. Of the remaining individual-level variables in the model, Master's and Ph.D. degree are significant. The coefficient on Masters Degree (7110.78) is significant at the 0.05 level, and can be interpreted as follows: having a Masters increases earnings by $\$ 7,110.78$, net of all the other factors in the model. Having a Ph.D. (25073.59) is significant at the 0.001 level and translates into an increase of $\$ 25,073.59$ percent in earnings, compared to those with a bachelor's degree.

The findings for job and occupational variables are as follows. Supervising the work of others is significant at the 0.001 level and increases earnings, net of the other variables in the model. Being a member of one or more professional societies is also significant $(p<0.05)$ and increases earnings by approximately $\$ 2,200$. Another jobrelated variable that is significant and has a very negative impact on earnings in LIS is working as a librarian as compared to an information scientist. The coefficient on the librarian variable is significant at the 0.001 level. It shows that librarians earn $\$ 30,155.63$ less than information scientists, all else being equal.

Labor market factors are also shown to be important. Working in the education, government and the non-profit sector, and being self-employed, decreases earnings compared to working in the for-profit sector. Those employed in the education sector earn $\$ 27,114.13$ less than those in the for-profit sector, and those in the government, nonprofit, and self-employment sectors earn $\$ 19,620.72$, $\$ 21,206.54$, and $\$ 37,090.35$ less than those in the for-profit sector. In addition to sector of employment, region of employment also plays an important role in earnings attainment. The results indicate that being employed in the North Central, South Central, and Mountain regions of the United States decreases earnings substantially relative to being employed in the Northeast. The coefficients on all three variables are negative and significant at the $0.001,01$, and 0.1 levels, respectively. 


\section{Discussion}

This study of the impact of gender, race and ethnicity on earnings found no significant differences between men and women or between racial and ethnic groups. Although it may be surprising that no differences were found, this is consistent with Lester Thurow's (1975) theory of job competition in the high-skilled segment of the labor market. He argues that once these highly competitive positions are successfully secured, individual background characteristics should become irrelevant and superseded by human capital factors. This may be counterintuitive and not consistent with many of the assumptions held by researchers studying this topic for years; however, it is a positive development and one that proves that human capital, job and occupational factors are the most important determinants of earnings. These results also illustrate that in a field that is disproportionately white and female; men and members of minority groups are not facing discrimination in the earnings attainment process.

Although the results are based on a sample of just 549 professionals working in library and information science, they form the basis for continued work in this area. The limitations of the study are clear. As the model of earnings attainment was developed, it was limited by pre-existing variables in the National Survey of College Graduates. An additional problem is the small sample size which leads to limitations in the generalizability of the results. For example, do these results apply to the entire discipline overall or to specific fields? It is difficult to answer these questions without further study and new, larger data sets. However, it is important to note that empirical studies of earnings in library science are few and this study will hopefully lead to more work in this

area. Possibilities for future research should include further examination of the impact of gender, race, and ethnicity on earnings and other attainment processes within the field, such as hiring, promotion, and access to managerial jobs. Another area for future research stemming from the results of this study should be a more in-depth examination of the relationship between networking, mentoring, and memberships in professional organizations on earnings and overall career success. This study illustrates that these factors are significant, impact the earnings attainment process, and could lead to a deeper understanding of the internal workings of the field of library and information science.

This research also sheds some light on the changes taking place in LIS. As discussed in the literature review, the field is trending towards information science and away from traditionally defined librarian jobs. According to Wilder (2002), the percentage of new hires and functional specialists increased 196 percent between 1985 and 2000, while lower paying library positions such as catalogers and public service generalists decreased by 45 percent and 37 percent respectively (Seaman, 2005; Wilder, 2002). As the shift from traditional library jobs to specialized, high-tech information science jobs continues, the demographic make-up of LIS will change. As illustrated in Table 3, there are large differences between those who identified themselves as librarians in the NSCG versus those who identified as information scientists. The 358 "librarians" in the sample are 76 percent female, 85 percent white, 6 percent Asian, with an average salary of $\$ 42,067.79$, whereas the 191 “information scientists” are 81 percent male, 72 percent white, 21 percent Asian, an average age of 41.4 years, and a mean salary of $\$ 83,740.71$. This is consistent with Hildenbrand's (1999) discussion of the gender divide 
in the field where she argues that schools and curriculum changes encourage gender differences, favor men over women; and steer women towards library science and men towards information science. If this trend continues, tensions between these subdisciplines of LIS may deepen, leading to fractures in the field or a more fragmented and unequal profession.

A very surprising result was that librarians earn $\$ 30,155.63$ less than information scientists. This is another factor that could lead to increased tensions within the field. Although LIS was analyzed as one discipline, profession and labor market, these findings provide support to the belief that the discipline may be too broadly defined. The results illustrate the vast differences between those who identify themselves as librarians and those who identify as information scientists. Hjorland (2000) argues that LIS can only become a science if it is able to formulate researchable problems. This study has presented a serious research question regarding the earnings attainment process and whether gender, race and ethnicity have a significant impact. The results have provided a partial answer to that question; however, they have also raised additional questions for LIS that future research should attempt to answer.

\section{Conclusion}

This study examined earnings in the library and information science labor market in relation to individual, job/occupational and labor market variables. The key findings are: 1) there is no significant difference in earnings between men, women, blacks, Asians, Hispanics, and Native Americans as compared to whites; 2) age is significant and positively impacts earnings; 3) possessing a Masters degree and a Ph.D. is important and positively impacts earnings; 4) being married has a positive and significant impact on earnings; 5) being active in the job in the form of taking on a supervisory role is significant and positively impacts earnings; 6 ) being active in the profession by joining professional societies is significant and positively impacts earnings; 7) sector and region of employment has a significant influence on earnings. 


\section{References}

Aharony, N. (2006). The librarian and the information scientist: Different perceptions among Israeli information science students. Library \& Information Science Research, 28, 235-248.

Allard, C. A. (1984). Assessing faculty salary equity. AIR Professional File, 20, 1-9.

Ashcroft, L. 2003. Raising Issues of Salaries and Status for Library/Information Professionals. New Library World, 104: 164-170.

Auster, E. R. (1989). Task characteristics as a bridge between macro- and micro level research on salary inequality between men and women. Academy of Management Review, $14,173-193$.

Averitt, R. T. (1968). The dual economy: The dynamics of American industry structure. New York: Norton.

Barbezat, D. A. (2003, Spring). From here to seniority: The effects of job tenure on faculty salaries. New Directions for Institutional Research, 117, 21-47.

Baron, J. N. (1991). Organizational evidence of ascription in labor markets. In R. R. Cornwall \& P.V. Wunnava (Eds.), New Approaches to Economic and Social Analysis of Discrimination (pp. 113-144). New York: Praeger.

Baron, J.N., \& Bielby, W.T. (1980). Bringing the firms back in: Stratification, segmentation, and the organization of work. American Sociological Review, 45, 737-765.

Becker, G. S. (1964). Human capital. New York: National Bureau of Economic Research

Beggs, J. J. (1995). The institutional environment: Implications for race and gender inequality in the U.S. labor market. American Sociological Review, 60, 612-633.

Bergman, B. J. (2005). Looking at electronic resources librarians: Is there gender equity within this emerging specialty? New Library World, 106, 116-127.

Bielby, W. T. (1991). The Structure and Process of Sex Segregation. In R.R. Cornwall \& P.V. Wunnava (Eds.), New Approaches to Economic and Social Analysis of Discrimination (pp. 97-112). New York: Praeger.

Bluestone, B., Murphy, W. M., \& Stevenson, M. (1973). Low wages and the working poor. University of Michigan-Wayne State University: Institute of Labor and Industrial Relations.

Borko, H. (1968). Information science: what is it? American Documentation, 19, 3-5. 
Burke, C. (2007). History of information science. Annual Review of Information Science and Technology, 41(1), 3-53.

Carmichael, J. V. (1992). The male librarian and the feminine image: A survey of stereotype, status, and gender perceptions. LISR, 14, 411-446.

Carson, C. H. (1996, October 15). Beginner’s Luck: A Growing Job Market. Library Journal, 29-35.

Charters, M. F., \& Grimes, P. W. (1997). Technology and librarianship: A test of the human capital model of occupational segregation. Applied Economic Letters, 4, 403-406.

Churched, Z. (2003). The impact of information technology on job requirements and qualifications for catalogers. Information Technology and Libraries, 21, 18-21.

Crosby, O. (2000). Librarians: Information experts in the information age. Occupational Outlook Quarterly, 4(4), 2-15.

Deyrup, M. M. (2004). Is the revolution over? Gender, economic, and professional parity in academic library leadership positions. College \& Research Libraries, 65, 242-250.

Doeringer, P. B., \& Piore, M. J. (1971). Internal labor markets and manpower analysis. Lexington, MA: Heath.

Eliason, S. R. (1995). An extension of the Sorenson-Kalleberg theory of the labor market matching and attainment process. American Sociological Review, 60, 247-271.

Fidishun, D. (2001). People Servers vs. Information Providers: The Impact of Service Orientation on Technology Training. Information and Technology Libraries, 20, 29-34.

Fleck, I., \& Bawden, D. (1995). The information professional: Attitudes and images. Journal of Librarianship and Information Science, 24(4), 215-226.

Graham, J. W., \& Smith, S. A. (2005). Gender differences in employment and earnings in science and engineering in the U.S. Economics of Education Review, 24, 341-354.

Granovetter, M. (1981). Towards a sociological theory of income differences. In Ivar Berg (Ed.), Sociological perspectives on labor markets (pp. 11-48). New York: Academic Press.

Granovetter, M. (1985). Economic action and social structure: The problem of embeddedness. American Journal of Sociology, 91, 481-520. 
Granovetter, M. (1991). The sociological and economic approaches to labor market analysis: A structural view. In M. Granovetter \& R. Swedberg (Eds.), The sociology of economic life (pp. 233-263). Boulder, CO: Westview Press.

Grimes, M. F., \& Grimes, P.W. (2008). The academic librarian labor market and the role of the master of library science degree: 1975 through 2005. The Journal of Academic Librarianship, 34, 332-339.

Harris, R. M., \& Tague, J.M. (1989). Reaching the top in Canadian librarianship: A biographical study of sex differences in career development. Library Quarterly, 59, 116130.

Hauser, R.M. (1980). On Stratification in a Dual Economy. American Sociological Review, 45, 702-712.

Hayes, R. M. (1969). Information science in librarianship. Libri, 19, 216-236.

Hildenbrand, S. (1999, April 15). The information age vs. gender equity. Library Journal, 44-47.

Hjorland, B. (2000). Library and information science: practice, theory, and philosophical basis. Information Processing and Management, 36, 501-531.

Kim, K., Chiu, M., Sin, S., \& Robbins, L. (2007). Recruiting a diverse workforce for academic/research librarianship: Career decisions of subject specialists and librarians of color. College \& Research Libraries, 68, 533-552.

Kalleberg, A., Wallace, M., \& Althauser, R. (1981). Economic segmentation, worker power, and income inequality. American Journal of Sociology, 87, 651-683.

Lee, D. O. (2005). Faculty status, tenure, and compensating wage differentials among members of the Association of Research Libraries. (Doctoral dissertation). Mississippi State University, Starkville, Mississippi, USA.

Lim, S. (2008). Job satisfaction of information technology workers in academic libraries. Library \& Information Science Research, 30, 115-121.

Lundy, M. (2003). Changing roles of the systems librarians at the College of William and Mary: The explosion of technology and position of the system librarian. Library Hi Tech, 21, 333-339.

Lynch, M. J. (1998). Librarians’ salaries: Smaller increases this year. American Libraries, 29 (10), 66-70.

Lynch, M. J. (2003, December). Association, know thyself. American Libraries, 76-77. 
Maatta, S. (2007). What's an MLIS worth? Library Journal, 132, 30-38.

Marco, G. (1996). Two false dogmas of information science. New Library World, 97(11), 11-14.

Olsson, L. (1995). Det datoriserade biblioteket: Maskindrömmar på 70-talet $<$ The computerized library: Machine dreams in the seventies>. Linköping: Linköpings universitet, Tema Teknik och social förändring (doctoral dissertation).

Passet, J. E. (1993). Men in a feminized profession: The male librarian, 1889-1921, Libraries \& Culture, 26, 385-402.

Pedhazur, E.J. (1982). Multiple regression in behavioral research: Explanation and Prediction ( $2^{\text {nd }}$ ed.). Orlando, Florida: Harcourt Brace Jovanovich.

Pfeffer, J. \& Davis-Blake, A. (1990). Determinants of salary dispersion in organizations. Industrial Relations, 29, 38-57.

Piper, P., \& Collamer, B.E. (2001). Male librarians: Men in a feminized profession. The Journal of Academic Librarianship, 27, 406-411.

Portes, A., \& Sensenbrenner, J. (1993). Embeddedness and immigration: Notes on the social determinants of economic action. American Journal of Sociology, 98, 1320-1350.

Prins, H., \& De Gier, W. (1992). Image, status and reputation of librarianship and information work. IFLA Journal, 18, 108-118.

Ransom, M. R. (1993). Seniority and monopsony in the academic labor market. The American Economic Review, 83, 221-233.

Scarth, L. L. (2002). Are we there yet?: Facing the never-ending speed and chance of technology in midlife. Library Trends, 50, 681-686.

Seaman, S. (2005). Salary compression in the association of research libraries. Libraries and the Academy, 5 (1), 77-91.

Smith, S. A. (1997). Assessing the impact of race and nativity on the careers of scientists and engineers: An analysis of selection and attainment processes in the scientific labor market. (Doctoral dissertation). Rutgers University, New Brunswick, New Jersey, USA.

Smith, S. A., Hartman, S., \& Crow, S. (2005). Attrition in nursing: Perspectives from the National Survey of College Graduates. The Health Care Manager, 24 (4), 336-346.

Stieg, M. (1992). Change and challenge in library and information science education. Chicago: ALA. 
Taylor, R. (1966). Professional aspects of information science and technology. In C. A. Cuandra (Ed.), Annual review of information science and technology (pp. 15-40). New York: Wiley.

Thurow, L. C. (1975). Generating inequality: Mechanisms of distribution in the U.S. economy. New York: Basic Books.

Turock, B. J. (2003). Developing diverse professional leaders. New Library World, 104, 491-499.

Webster, A. L. (1995). Demographic factors affecting faculty salary. Educational and Psychological Measurement, 55, 728-735.

Wilder, S. J. (2002, April). New Hires in Research Libraries: Demographic Trends and Hiring Priorities, ARL Bimonthly Report 221. Retrieved from http://www.arl.org/newslte/221/newhires

Zemon, M., \& Bahr, A. H. (2005). Career and/or children: Do female academic librarians pay a price for motherhood. College \& Research Libraries, 66, 394-406. 